Article

\title{
Investment in Research and Development and New Technological Adoption for the Sustainable Beekeeping Sector
}

\author{
Jelena Vapa-Tankosić $^{1, * \mathbb{C}}$, Vera Miler-Jerković ${ }^{2}$, Dejan Jeremić ${ }^{3}$, Slobodan Stanojević 4 \\ and Gordana Radović 5 \\ 1 Department of Business Economics and Finance, Faculty of Economics and Engineering Management in \\ Novi Sad, University Business Academy in Novi Sad, Cvećarska 2, 21000 Novi Sad, Serbia \\ 2 School of Electrical Engineering, University of Belgrade, Bulevar kralja Aleksandra 73, 11000 Belgrade, \\ Serbia; veramiler@gmail.com \\ 3 Faculty of Business and Financial Studies, University of Business Studies in Banja Luka, Jovana Dučića 23a, \\ 78000 Banja Luka, Bosnia and Herzegovina; djeremic@sequestergroup.com \\ 4 Faculty of Applied Management, Economics and Finance, University Business Academy in Novi Sad, \\ Jevrejska 24/1, 11000 Belgrade, Serbia; sloba_leo@yahoo.com \\ 5 Dnevnik-Poljoprivrednik AD Novi Sad, Bulevar Oslobođenja 81, 21000 Novi Sad, Serbia; \\ gordana.radovic09@gmail.com \\ * Correspondence: jvapa@libero.it
}

Received: 22 June 2020; Accepted: 15 July 2020; Published: 20 July 2020

check for updates

\begin{abstract}
The purpose of this paper is to understand how members of beekeeping associations, with long-standing sustainable traditions and products with registered geographical origins, perceive the investments in research and development (R\&D) and new technological adoptions. By means of a binary logistic regression, the socio-demographic factors of the members of beekeeping associations predicting the investments in R\&D and new technological adoptions were analyzed. Our findings point out that higher level of education and professional beekeeping experience predicts the willingness of investing in research and development. The higher level of education positively influences the willingness to hire professional consultants or bodies for the research and development of beekeeping practices. Serbian female beekeepers, beekeepers aged more than 41 years and professionally engaged beekeepers are more likely to admit that they need support of scientific and research institutions in the further development of beekeeping practices. A higher education has been shown to significantly predict the value added hive products due to new technology adoption. There is also a positive influence of the education level on new technology adoption.
\end{abstract}

Keywords: apiculture investment; research and development; sustainability; beekeepers; honey; geographical origin; food; label

\section{Introduction}

Beekeeping is a very important sector in European agriculture. In recent years, the honey market in the EU has been showing a constant increase in demand. In the period of 2017-2019, 216 million EUR will be spent on national beekeeping programs in $28 \mathrm{EU}$ member states, an increase of $9 \%$ from the 2014-2016 budget period with an increase in the number of beekeeping incentive measures from six to eight [1-3]. According to the data of the ANSES Sophia Antipolis laboratory, designated as the European Union Reference Laboratory for bee health [4], the total number of beekeepers in Europe was estimated at 620,000 in 2010 . The European honey production was evaluated at around 220,000 tons in 2010. The price of honey varied from 1.5 to $40 \mathrm{EUR} / \mathrm{kg}$ and the estimated colony winter mortality 
varied from $7 \%$ to $28 \%$ depending on the country and the origin of the data. The beekeeping industry has a specific role and is different from other food productions, having in mind that the size of the apiary is generally small (22.4 colonies/beekeeper) while most beekeepers were still hobby beekeepers or "non-professional" beekeepers [4]. One of the current proposals at the EU level, in the scope of beekeeping research is focused on promotion of initiatives to boost European beekeeping research projects [5].

The European integration agenda has an aim to promote a higher level of awareness for health and environmental sustainability in countries that are EU candidates, including the Republic of Serbia. The authors findings [2] point out that Serbian consumers of organic honey are willing to pay (WTP) up to $20 \%$ over the price of conventional honey. Understanding customer needs is a key factor in retaining them, as well as acquiring new customers in the process of achieving greater market share [6]. It is necessary to timely allocate efficient and sustainable use of ecological goods [7]. Ignjatijević and Cvijanović [8] point out that the current economic and political position of Serbia imposes the need to analyze the comparative advantages of the agro business sector, especially if it is known that Serbia has a significant potential that is not sufficiently exploited. The honey market in the Republic of Serbia is gradually developing since, in the period from 2004 to 2013, the average value of the exported honey from Serbia amounted to 4.79 million dollars, and imports to 62.4 thousand dollars. The exported quantities of honey indicate a significant increase at the rate of $61.74 \%$ per annum. Germany and Italy are the leading countries for import of honey from the Republic of Serbia. Monitoring the variations in comparative advantages in export in the Republic of Serbia transition period and accession to the EU is important for the analysis of the effects of trade liberalization and integration in international flows of the honey sector [9].Western Balkan exporters are gradually positioning themselves on the markets of the EU and countries of ex-Yugoslavia (CEFTA) [10]. The Republic of Serbia has achieved a positive comparative advantage in exports of the processed food sector [11]. High export and minimal import values contributed to Serbia's positive comparative advantage (RCA) in the export of agricultural and food products, sugar industry, molasses [12] and especially honey [13,14]. Research shows that EU countries, especially Germany and Italy, are the target markets for the export of Serbian honey [6]. Ignjatijević et al. [15] suggest that "companies must continually work on the sustainable development of trade by applying new technologies in management".

Bearing in mind the developing honey market, the aim of the present study is to analyze how the beekeeping association members of honey with a registered geographical origin "Fruškogorski lipov med" (Fruška Gora linden honey) perceive investments in R\&D and new technological adoptions. The specific aims of this paper are: (a) to investigate the attitudes of beekeeping association members towards investments in R\&D and new technological adoptions, and (b) to identify socio-demographic factors that contribute to predicting the investment in R\&D and the new technological adoption. In light of the aim of the paper, several hypotheses have been defined:

Hypothesis 1. A beekeeping association member's education and professional engagement in beekeeping positively predicts their willingness to invest in the investment in research and development and engage professional bodies for the research and development of beekeeping production.

Hypothesis 2. A beekeeping association member's willingness to rely on support of scientific and research institutions in the further development of beekeeping practices is positively predicted by their gender, age and professional engagement in the beekeeping.

Hypothesis 3. The need for significant funds and further research in the development of beekeeping practices is positively predicted by the beekeeping association member's age, family size, number of beehives and professional engagement in beekeeping.

Hypothesis 4. Beekeepers with larger families are more prepared to use new technologies, which is positively predicted by the beekeeping association member's number of beehives, level of education and family size. 
Hypothesis 5. A higher education positively predicts the perception of new technology adoption and the subsequent increase in the value added hive products.

For this research, the authors have chosen beekeeping association with a registered label of geographic origin, "Fruška Gora linden honey", which has received a label of geographic origin in 2015, thanks to the support of EU funds in the process of certification. The concept of honey quality integrates the features of the honey production process with the social and environmental impacts, animal welfare and the link of the food with a certain agricultural area. The later aspect at European Union level can be achieved by obtaining two designations: Protected Designation of Origin and Protected Geographical Indication [5]. Authenticity and traceability are the main aspects in the case of the Protected Designation of Origin or the Protected Geographical Indication recognition process [13]. According to Bertozzi [16], the use of geographical name for an agricultural product dates from ancient times: "honey from Sicily" is a good example in this sense. The research findings of Pocol et al. [17] have shown the significance of supplying honey with a protected geographic origin status, while emphasizing several European Countries where honey is protected by the protected designation of origin/protected geographical indication status: Greece, Spain, France, Italy, Luxembourg, Malta, Poland, Portugal and Ukraine. In Italy those are "Miele della Lunigiana", registered from 2004 [18], "Miele delle Dolomiti Bellunesi" registered from 2011 [19], and "Miele Varesino", registered in 2014 [20]. In Romania, the Ministry of Agriculture and Rural Development encourages the protected designation of origin/protected geographical indication honey certification [21]. On the other hand, while the United Kingdom is pursuing withdrawal from the European Union, the Protected designations of origin, the Protected geographical indications, the Geographical indications and Traditional specialties, in force in the EU-27 Member States, may be subject to securing alternative ways of protection of the relevant geographical names in the United Kingdom, as per United Kingdom law [18].

Recent findings on consumer attitudes, shows that majority of consumers, as many as $83 \%$, are willing to try Fruška Gora's linden honey that is of above average quality and is certified, regardless of the fact that linden honey does not belong to the type of honey which consumers usually buy. The consumers are willing to pay even a $30 \%$ higher price than the average market price of noncertified linden honey [22]. It should also be mentioned that this study is among the first to empirically analyze the current issues in the Serbian beekeeping sector. Thus, field research was conducted to collect the technical and economic data necessary for this study. More specifically, a structured questionnaire was completed by 250 Serbian beekeepers, from March to December 2019.

\section{Literature Review}

A plethora of various studies has pointed out the significance of beekeeping associations. Ferreira et al. [23] pointed out the economic effects of the associations in terms of the impact on employment regardless of nationality [24], while Androulidakis and Harizanis [25] emphasized the importance of the associations in organized beekeeping education, technical support, providing relevant statistical data [26], clarifying or interpreting legislation [27], strengthening entrepreneurial orientations [28] and marketing the performance of honey and honey products [29], market positioning [30] and more. Pocol et al. [31] point out the importance of beekeepers' associations in establishing cooperation with other beekeepers, while Popa et al. [27] point out that associations should cooperate with other beekeeping associations, but also with other companies, in order to modernize beekeeping. According to Mushonga et al. [32], local authorities should promote the establishment of beekeeping associations as the findings show that the beekeepers' operations should be supported by education and training.

The issue of the efficiency of investing in beekeeping has been analyzed by Ismail and Ismail [33], indicating that assistance in the form of cheaper loans for the purchase of bees is the most effective initial investment. The authors conclude that the final effects of investment in beekeeping shall be the reduction of rural and urban poverty. Grgić et al. [34] have investigated the beekeeping sector 
of the Mediterranean area by conducting an analysis of investments, yields and income and have concluded that investments per hive are around 316 to 395 EUR, where the largest investments are in the categories of small and large beekeepers and in the procurement of vehicles and trailers for migration beekeeping. Grgić et al. [35] have conducted an assessment of the main factors of economic performance, the justification of the investment in the bee colony migration system and the increase in the range of hive products. They have presented two investment models: in the first model the stationary way of beekeeping was retained, while migration beekeeping was presented in the other model. The authors conclude that the migration of bee colonies affects the pasture conditions and thus produces an average of $60 \mathrm{~kg}$ of honey per hive.

The increased collaboration of beekeepers with science and real sector stakeholders [36], development of social entrepreneurship [37] and development of entrepreneurial behavior, would contribute to a decrease in the total of (especially rural) unemployment $[2,17,28,38-40]$. In fact, Pocol et al. [41], as well as other researchers [42], have concluded that establishing social beekeeping enterprises may represent an innovative answer to minimizing social problems and can preserve local specificity, promote traditional agriculture and create additional local branded products. New technological adoption and investment in R\&D in the apiculture sector should be crucial in order to add value to the product and improve beekeeping practices, including bee health and apiary management. Developing new beekeeping methods and raising awareness of good practices should be done with the help of professional bodies and research institutes. "Investment in knowledge infrastructure and $R \& D$ is an important component of any science, technology and innovation policy as well as building up of a set of linkages between main actors and the encouragement of productive interactions and learning processes among them in the context of national, sectoral, regional and in fact transnational systems of innovation" [43].

Keiyoro et al. [44] have revealed that sociocultural factors have a positive and negative influence on the adoption of beekeeping technologies. The study, on the comparison of the new technology adoption rate and income through beekeeping at the farmers' level, has shown that the transfer of improved technology to farmers could help generate income and alleviate poverty [45]. The findings of a study by Popescu and Siceanu [46] in Romania argues that the use of the new reproduction techniques based on the instrumental insemination of queen bees is not only a valuable way for improving bee-breeding programs, but is also a possibility to change the actual apiaries into sustainable and modernized beekeeping farms. The findings of a study on the perception of farmers towards the use of modern beehive technology in Ethiopia showed that education, the off-farm income, availability of credit, beekeeping training and perception in the price of box hives were important factors influencing the adoption of modern beehive technology, recommending that credit should also be given as a part of the package for the proper adoption of this technology [47]. The findings also revealed that beekeepers in Nigeria have increased the quantity of honey produced with a significant difference in the level of the use of modern beekeeping technologies before and after the training [48]. A study of the determinants of technical efficiency of beekeeping farms in Turkey [49] and the association between the beekeeping subsidies and farm efficiency, using a stochastic frontier analysis on beekeeping farming, showed that the beekeepers were generally found to be fairly inefficient thus "increasing of education level of farmer was found as one of the important determinants of efficiency due to access to information, good farm management and adaptation of new production methods". The findings of a study on the factors affecting the adoption of beekeeping and associated technologies in India [50] underline the most important constraints in beekeeping, such as a lack of equipment, pest and predator attacks, bad weather, lack of credit, inadequate skill and knowledge, fear of bees, lack of starting capital to buy hives and equipment, level of income, information on technology and the other technicalities involved. The findings of Muya et al. [51] show that the following economic factors influenced the adoption of beekeeping technologies: product prices, substitute product prices, consumer income, beekeeper's income and government policies. 


\section{Materials and Methods}

A product of the society of beekeepers "Jovan Živanović" from Novi Sad, Region of Vojvodina that lies in the north of the Republic of Serbia, established in 1973, was used. Their product "Fruška Gora linden honey" has recently received a product quality certificate, which represents a chance to contribute to a greater visibility of the Fruška Gora linden honey in the world market and further promote beekeeping as a potentially profitable and environmentally-friendly business. The entire product is traditionally produced in the specific region of Fruška Gora. For these reasons, the beekeepers "Jovan Živanović" from Novi Sad have been chosen for participation in the study.

The research was carefully prepared. The survey was conducted in the territory of Vojvodina, from March to December 2019, and the questionnaire was tested in cooperation with the Association of Beekeeping Organizations of Vojvodina to improve its validity and reliability. The research was directed towards honey with a geographical indication, therefore it was decided that the target group was the members of the Society of beekeepers "Jovan Živanović" from Novi Sad, with whom the Faculty of Economics and Engineering Management in Novi Sad has already collaborated on several projects. The initial questionnaire was improved based on the suggestions of the management of the focus group. The survey was electronically sent to all of the members (in total, 294), while 250 questionnaires were returned in full. The response rate was $85 \%$. The questionnaire was created according to previous research on the application of innovations in the beekeeping industry [3] and the perceived factors towards the use of modern technologies in beekeeping [3,44,47]. All instrument items, except for the socio-demographical characteristics, were answered on a five-point psychometric Likert scale (anchored on 1-"strongly disagree" through 5-"strongly agree"). Likert-type scales usually contain either five or seven response categories [52]. The literature suggests that a five-point scale appears to be less confusing and increases response rates [53], so the authors opted for the five-point Likert scale. A questionnaire that consisted of three sets of questions was prepared. The first group of questions assessed the socio-demographic characteristics of beekeepers (e.g., sex, number of hives, education, family size, age and engagement in beekeeping). The second group consisted of statements regarding the characteristics of investment in R\&D in beekeeping (e.g., I am willing to invest funds in the research and development of beekeeping production; I am willing to engage professionals bodies for the research; I need support of scientific and research institutions in the further development of beekeeping practices; Significant funds and further research in the development of beekeeping practices is needed). The third group consisted of statements which indicate the characteristics of the new technological adoptions in beekeeping (e.g., beekeepers with larger families are more willing to use new technologies; new technology adoption can increase the value added hive products; education levels can positively influence new technology adoption).

Thus, field research was conducted to collect the empirical data necessary for this study. The answers that were received in full totaled 250 respondents (response rate $83 \%$ ) and were further elaborated. The qualitative and quantitative data were analyzed and the appropriate statistical tools and techniques were employed. Several different models have been tested for each dependent variable, IRD 1, 2, 3, 4 and NTA 1, 2, 3, in order to find the best model. At the start, the ordinal logistic regression was conducted with the complementary clog-log link function, with the following set of predictors: sex, number of beehives, education, family size, age, and engagement in beekeeping. Additionally, for each model, a backward step analysis was conducted to find the optimal model. This analysis was used to determine if any of the independent variables can be excluded. However, the accuracy of the original model was small (less than $50 \%$ ), and this is the reason why the alternative model was used. Improvement was achieved by a reduction of the categories of the independent variables and the models were tested again. Further on, because the accuracy of the new models was small (less than $60 \%$ ), the alternative model has been produced, in which a dependent variable was gradually collapsed. Finally, for the purpose of a higher accuracy, the dependent variables have been collapsed into two levels and we ran a binary logistic regression. In order to determine the optimum threshold value for a binary logistic regression, we used the receiver operator characteristic curve (the ROC 
curve). The optimization method which has been used is the iteratively reweighted least squares (IRLS). For the imbalanced data, the SMOTE technique was used. For all models, the ratio of the train and the test has been set on a 80-20 ratio [54]. The authors wanted to find the best fitting model. The best model was set as the model with the highest accuracy. The data was processed in the R Studio software (Version 0.98.976).

\section{Results}

\subsection{Demographic Analysis of the Respondents}

The final sample consisted of 250 respondents, of whom 16 (6.4\%) were female and $234(93.6 \%)$ were male. On average, they were 38.7 years of age. The $73(29.2 \%)$ beekeepers were $26-40$ years old. The $96(38.4 \%)$ of beekeepers were $41-55$ years old. The 81 (32.4\%) beekeepers were over 55 years old. In the entire sample, 161 (64.4\%) beekeepers completed high school, while $89(35.6 \%)$ of the beekeepers completed college or had a higher education. One hundred and five $(42 \%)$ of the beekeepers have a small family (up to three members) while 145 (58\%) have a bigger family (four or more members). The $32(12.8 \%)$ beekeepers have a maximum of 10 beehives, $104(41.6 \%)$ of them have 10 to 25 bee hives, while $114(45.6 \%)$ have more than 25 bee hives.

Table 1 shows the characteristics of investment in the R\&D of beekeeping. The beekeepers do invest funds in the research and development of beekeeping (mean average of 3.74) and they are willing to hire experts in the research and development of beekeeping practices. They agree that additional funds and further research in the field of beekeeping is needed. The beekeepers believe they need the support of scientific and research institutions in the further development of beekeeping practices (mean average of 4.64).

Table 1. Characteristics of the investment in the research and development (R\&D) of beekeeping.

\begin{tabular}{|c|c|c|c|}
\hline & Characteristics of Investment in R\&D & Mean & SD \\
\hline IRD1 & $\begin{array}{c}\text { I am willing to invest funds for research and development of } \\
\text { beekeeping production }\end{array}$ & 3.74 & 1.41 \\
\hline IRD2 & I am willing to engage professionals bodies for the research & 3.32 & 1.18 \\
\hline IRD3 & $\begin{array}{l}\text { I need support of scientific and research institutions in the } \\
\text { further development of beekeeping practices }\end{array}$ & 3.50 & 1.43 \\
\hline IRD4 & $\begin{array}{l}\text { Significant funds and further research in the development of } \\
\text { beekeeping practices is needed }\end{array}$ & 4.64 & 0.65 \\
\hline
\end{tabular}

Table 2 shows the characteristics of the new technological adoptions in beekeeping. The beekeepers are well aware that the education level positively influences the adoption of new technologies (mean average of 4.19) and that this may increase their production and introduction of new value-added products (mean average of 4.19 ).

Table 2. Characteristics of the new technological adoptions in beekeeping.

\begin{tabular}{cccc}
\hline \multicolumn{2}{c}{ Characteristics of New Technological Adoption } & Mean & SD \\
\hline NTA1 & $\begin{array}{c}\text { Beekeepers with larger families are more } \\
\text { prepared to use new technologies }\end{array}$ & 3.64 & 1.09 \\
\hline NTA2 & $\begin{array}{c}\text { New technology adoption can increase the } \\
\text { value-added hive products (such as royal } \\
\text { jelly, propolis, bee pollen and beeswax) }\end{array}$ & 4.19 & 0.97 \\
\hline NTA3 & $\begin{array}{c}\text { Education level can positively influence } \\
\text { new technology adoption }\end{array}$ & 4.19 & 0.93 \\
\hline
\end{tabular}




\subsection{Main Results of the Investigation}

The aim of the research was to detect the interdependence between the nominal outcomes, which were: new technological adoption and investment in $R \& D$, and the socio-demographic characteristics of beekeepers (e.g., sex, number of beehives, education, family size, age and engagement in beekeeping).

For IRD1, the accuracy of an ordinal model with the modified independent variables was $49.01 \%$, whereas the accuracy of a logistic model was higher, at $63.26 \%$. The backward procedure did not see any significant improvement. For the model based on a logistic regression, the optimal threshold was set at 0.75 . Table 3 represents the results given from a logistic regression with the dependent variable IRD1 and the set of predictors.

Table 3. Impact of the socio-demographic predictors on IRD1.

\begin{tabular}{ccccc}
\hline & Estimate Coefficient & Odds Ratio & Test Statistics & \multicolumn{2}{c}{ Significance Level } \\
\hline (Intercept) & -3.11 & 0.04 & -3.27 & $<0.001$ \\
\hline Sex (female) & -18.23 & 0.01 & -0.02 & 0.99 \\
\hline Number of beehives (10-25) & 0.56 & 1.75 & 1.04 & 0.31 \\
\hline Number of beehives (>25) & -0.66 & 0.52 & -1.29 & 0.21 \\
\hline Education (higher) & 1.47 & 4.36 & 3.45 & $<0.001^{* *}$ \\
\hline Family (bigger) & 0.68 & 1.97 & 1.82 & 0.07 \\
\hline Age (41-55) & 0.25 & 1.29 & 0.61 & 0.55 \\
\hline Age (>55) & -0.02 & 0.98 & -0.05 & $<0.001{ }^{* *}$ \\
\hline Professional (Yes) & 2.57 & 13.05 & 3.47 &
\end{tabular}

Only two independent variables from the set of predictors (higher education and professional engagement in beekeeping) made a statistically significant contribution to the model with regard to the dependent variable IRD1 (I am willing to invest funds for the research and development of beekeeping production). The strongest predictor of the above-mentioned statement that respondents invest in research and development was their professional engagement in beekeeping, recording an odds ratio of 13.05. This indicates that the respondents who engage in professional beekeeping are 13.05 times more likely to agree to invest in research and development, than those who engage in beekeeping as an additional job, controlling for all other factors in the model. The beekeepers that are more educated (having finished a college or a university) are 4.36 times more likely to agree with the statement that they invest in research and development than beekeepers that have only finished high school, controlling for other factors in the model.

For IRD2, the accuracy of an ordinal model with the modified independent variables was $44.12 \%$, whereas the accuracy of a logistic model was higher, at $89.80 \%$. The backward procedure did not see any significant improvement. For the model based on a logistic regression, the optimal threshold was set at 0.50 . Table 4 represents the results given from a logistic regression with the dependent variable IRD2 and the set of predictors. The independent variable (higher education) made a unique, statistically significant contribution to the model with regard to the dependent variable IRD2 (I am willing to engage professional bodies for the research and development of beekeeping practices). The only significant predictor of the above-mentioned statement, that respondents should engage professional bodies for the research and development of beekeeping practices, was higher education, recording an odds ratio of 13.27. This indicates that the respondents that are more educated (having finished a college or a university) are 13.27 times more likely to agree with the statement that they should engage professional bodies for the research and development of beekeeping practices, than those who only finished high school, controlling for other factors in the model. 
Table 4. Impact of the socio-demographics predictors on IRD2.

\begin{tabular}{ccccc}
\hline & Estimate Coefficient & Odds Ratio & Test Statistics & Significance Level \\
\hline (Intercept) & -19.13 & 0.01 & -0.01 & 0.99 \\
\hline Sex (female) & -18.51 & 0.01 & -0.01 & 0.99 \\
\hline Number of beehives (10-25) & -17.86 & 0.01 & 0.01 & 0.99 \\
\hline Number of beehives (>25) & -18.25 & 0.01 & 0.01 & 0.99 \\
\hline Education (higher) & 2.58 & 13.27 & 4.96 & $0.001^{* *}$ \\
\hline Family (bigger) & -0.15 & 0.86 & -0.34 & 0.22 \\
\hline Age (41-55) & 0.59 & 1.81 & 1.23 & 0.33 \\
\hline Age (>55) & 0.48 & 1.61 & 0.97 & 0.51 \\
\hline Professional (Yes) & 0.42 & 1.53 & 0.66 &
\end{tabular}

For IRD3, the accuracy of an ordinal model with the modified independent variables was $59.11 \%$, whereas the accuracy of a logistic model with the SMOTE technique was $90.61 \%$. The backward procedure did not see any significant improvement. For the model based on a logistic regression, the optimal threshold was set at 0.25 . Table 5 represents the results obtained from a logistic regression with the dependent variable IRD3 and the set of predictors.

Table 5. Impact of the socio-demographics predictors on IRD3.

\begin{tabular}{ccccc}
\hline & Estimate Coefficient & Odds Ratio & Test Statistics & Significance Level \\
\hline (Intercept) & -2.69 & 0.07 & -24.27 & $<0.001$ \\
\hline Sex (female) & 0.24 & 1.27 & 2.14 & 0.03 \\
\hline Number of beehives (10-25) & -2.31 & 0.10 & -31.29 & $<0.001^{* *}$ \\
\hline Number of beehives (>25) & -3.01 & 0.05 & -38.95 & $<0.001^{* *}$ \\
\hline Education (higher) & 0.06 & 1.07 & 1.54 & 0.12 \\
\hline Family (bigger) & -1.24 & 0.29 & -30.75 & $<0.001^{* *}$ \\
\hline Age (41-55) & 2.41 & 10.97 & 29.82 & $<0.001^{* *}$ \\
\hline Age (>55) & 2.29 & 9.88 & 30.79 & $<0.001^{* *}$ \\
\hline Professional (Yes) & 1.71 & 5.45 & 18.61 & $<0.0011^{* *}$ \\
\hline
\end{tabular}

Five of the independent variables (all except higher education) made a statistically significant contribution to the model with regard to the dependent variable IRD3 (I need the support of scientific and research institutions in the further development of beekeeping practices). The strongest significant predictor of the above-mentioned statement, that the respondents need the support of scientific and research institutions in the further development of beekeeping practices, was age (41-55), recording an odds ratio of 10.97. This indicates that the respondents aged 41-55 are 10.97 times more likely to agree with the statement than those aged 26-40, controlling for other factors in the model. The beekeepers older than 50 are 9.8 times more likely to agree with the statement than those aged 26-40, controlling for other factors in the model. The respondents who are engaged in professional beekeeping are 5.5 times more likely to agree with the previous statement, that they need the support of scientific and research institutions in the further development of beekeeping practices, than those who engage in beekeeping as an additional job, controlling for all other factors in the model. Regarding the female beekeepers, they are 1.27 times more likely to agree with the statement than men, controlling for other factors in the model. The respondents that have 10 to 25 beehives are 0.1 times less likely to agree with the statement than those who have less than 10 beehives. The respondents that have more than 25 beehives are 0.05 times less likely to agree that they need the support of scientific and research 
institutions in the further development of beekeeping than those who have less than 10 beehives. The beekeepers that have a bigger family are 0.29 times less likely to agree with the statement than those with a smaller family.

For IRD4, the accuracy of an ordinal model with the modified independent variables was $59.19 \%$, whereas the accuracy of a logistic model with the SMOTE technique was $90.6 \%$. The backward procedure did not get any significant improvement. For the model based on a logistic regression, the optimal threshold was set at 0.25 . Table 6 represents the results obtained from a logistic regression with the dependent variable IRD4 and the set of predictors.

Table 6. Impact of the socio-demographics predictors on IRD4.

\begin{tabular}{ccccc}
\hline & Estimate Coefficient & Odds Ratio & Test Statistics & \multicolumn{2}{c}{ Significance Level } \\
\hline (Intercept) & -42.7 & $<0.001$ & -0.14 & 0.89 \\
\hline Sex (female) & 1.12 & 3.08 & $<0.001$ & 0.99 \\
\hline Number of beehives (10-25) & 1.05 & 2.85 & 11.9 & $<\mathbf{0 . 0 0 1} * *$ \\
\hline Number of beehives (>25) & -0.99 & 0.37 & -11.88 & $<\mathbf{0 . 0 0 1} * *$ \\
\hline Education (higher) & -1.51 & 0.22 & -21.12 & $<\mathbf{0 . 0 0 1}$ ** $^{* *}$ \\
\hline Family (bigger) & 2.55 & 12.86 & 32.23 & 0.91 \\
\hline Age (41-55) & -19.13 & $<0.001$ & 0.12 & 0.90 \\
\hline Age (>55) & -21.39 & $<0.001$ & 0.13 & 0.94 \\
\hline Professional (Yes) & -20.04 & $<0.001$ & 0.08 &
\end{tabular}

As shown in Table 6, four of the independent variables (number of beehives 10-25 and $>25$, and higher education and family size) made a statistically significant contribution to the model with regard to the dependent variable IRD4 (significant funds and further research in the development of beekeeping practices are needed). The strongest significant predictor of this statement was having a bigger family, recording an odds ratio of 12.88. This indicates that the respondents with bigger families are 12.8 times more likely to agree with the statement than those with smaller families (up to four members), controlling for other factors in the model. The beekeepers that have between 10 and 25 beehives are 2.85 times more likely to agree that significant funds and further research in the development of beekeeping practices are needed (compared to those who have fewer than 10 beehives). The beekeepers that have more than 25 beehives are 0.37 times less likely to agree that significant investments and further research in the development of beekeeping are needed than those who have less than 10 beehives. The beekeepers with a higher education are 0.22 times less likely to agree that significant investments and further research in the development of beekeeping are needed.

For NTA1, the accuracy of an ordinal model with the modified independent variables was $41.87 \%$ whereas the accuracy of a logistic model was $70.39 \%$. The backward procedure did not get any significant improvement. For the model based on a logistic regression, the optimal threshold was set at 0.50 . Table 7 represents the results given from a logistic regression with dependent variable NTA1 and the set of predictors. 
Table 7. Impact of the socio-demographics predictors on NTA1.

\begin{tabular}{ccccc}
\hline & Estimate Coefficient & Odds Ratio & Test Statistics & Significance Level \\
\hline (Intercept) & -1.21 & 0.30 & -1.48 & 0.14 \\
\hline Sex (female) & 0.33 & 1.39 & 0.40 & 0.69 \\
\hline Number of beehives (10-25) & 0.81 & 2.24 & 1.30 & 0.20 \\
\hline Number of beehives (>25) & 1.52 & 4.59 & 2.59 & $0.01^{*}$ \\
\hline Education (higher) & 1.33 & 3.80 & 3.47 & $<0.001^{* *}$ \\
\hline Family (bigger) & 0.91 & 2.49 & 2.39 & $0.02^{*}$ \\
\hline Age (41-55) & -1.19 & 0.30 & -2.70 & $0.01^{*}$ \\
\hline Age (>55) & 0.60 & 1.82 & 1.42 & 0.16 \\
\hline Professional (Yes) & -0.88 & 0.41 & -1.51 & 0.13 \\
\hline
\end{tabular}

Significant at $*<0.05, * * p<0.01$

Four of the independent variables (number of beehives $>25$, higher education, bigger family, age 41-55) made a statistically significant contribution to the model with the dependent variable NTA1 (beekeepers having large families are more prepared to use new technologies). The strongest significant predictor of the previous statement is beekeepers having more than 25 beehives, recording an odds ratio of 4.59 . This indicates that the beekeepers with more than 25 beehives are 4.59 times more likely to agree with this statement than those beekeepers with fewer than 10 beehives, controlling for other factors in the model. The beekeepers that have a higher education (having a college or university degree) are 3.8 times more likely to agree that beekeepers with large families are more prepared to use new technologies than those with finished high school. The beekeepers with a larger family (more than four members) are 2.49 times more likely to agree with the statement that beekeepers with large families are more prepared to use new technologies, than those with a smaller family. The beekeepers aged 41-55 are 0.3 times less likely to agree with the statement than the beekeepers aged 26-40, controlling for other factors in the model.

For NTA2, the accuracy of an ordinal model with the modified independent variables was 51.92\% whereas the accuracy of a logistic model with the SMOTE technique was 92.23\%. The backward procedure did not see any significant improvement. For the model based on a logistic regression, the optimal threshold was set at 0.20 . Table 8 represents the results given from a logistic regression with the dependent variable NTA2 and the set of predictors. In Table 8, we can see that the strongest significant predictor of the statement indicating that that the adoption of new technologies increases the value added hive products was higher education, recording an odds ratio of 18.81 . The beekeepers with a higher education were 18.81 times more likely to agree that the adoption of new technologies increases their production of the value added hive products.

Table 8. Impact of the socio-demographics predictors on NTA2.

\begin{tabular}{ccccc}
\hline & Estimate Coefficient & Odds Ratio & Test Statistics & \multicolumn{2}{c}{ Significance Level } \\
\hline (Intercept) & -0.48 & 0.62 & -3.56 & $<0.001$ \\
\hline Sex (female) & -18.56 & 0.001 & -0.13 & 0.89 \\
\hline Number of beehives (10-25) & -0.10 & 0.91 & -0.97 & $<.33$ \\
\hline Number of beehives (>25) & -0.33 & 0.72 & -3.21 & $<0.001^{* *}$ \\
\hline Education (higher) & 2.94 & 18.81 & 39.73 & $<0.001^{* *}$ \\
\hline Family (bigger) & -2.95 & 0.05 & -44.95 & $<0.001^{* *}$ \\
\hline Age (41-55) & -0.99 & 0.37 & -12.95 & $<0.001^{* *}$ \\
\hline Age (>55) & -1.99 & 0.14 & -0.74 & $<0.001^{* *}$ \\
\hline Professional (Yes) & -0.07 & 0.94 & 0.46 &
\end{tabular}

Significant at ${ }^{* *} p<0.01$. 
On the other hand, the beekeepers with larger families (more than four members), compared to beekeepers with fewer family members, are 0.05 less likely to agree that the adoption of new technologies increases their production of value added hive products. The beekeepers who have more than 25 beehives are 0.72 less likely to agree that the adoption of new technologies increases their production offer compared to the ones who have fewer than 10 beehives. The beekeepers aged 41-55 years are 0.37 times less likely to agree with the statement than those aged 26-40, controlling for other factors in the model. The beekeepers older than 50 are 0.14 times less likely to agree with the statement than those who are aged 26-40, controlling for other factors in the model.

For NTA3, the accuracy of an ordinal model with the modified independent variables was $58.13 \%$, whereas the accuracy of a logistic model was $81.63 \%$. The backward procedure did not see any significant improvement. For the model based on a logistic regression, the optimal threshold was set at 0.60. Table 9 shows the results given from a logistic regression with the dependent variable NTA3 and the set of predictors. In Table 9 we can see that the strongest significant predictor of the statement indicating that the education level can positively influence new technology adoption was higher education, recording an odds ratio of 4.3. The beekeepers with a higher education are 4.3 times more likely to agree that the education level can positively influence new technology adoption, compared to beekeepers with lower education levels. The beekeepers with larger families compared to beekeepers with fewer family members are 0.36 times less likely to agree that the educational level in beekeeping can positively influence new technology adoption. The beekeepers aged $41-55$ years are 0.14 times less likely to agree than those aged 26-40, controlling for other factors in the model.

Table 9. Impact of the socio-demographics predictors on NTA3.

\begin{tabular}{ccccc}
\hline & Estimate Coefficient & Odds Ratio & Test Statistics & \multicolumn{2}{c}{ Significance Level } \\
\hline (Intercept) & -18.18 & 0.001 & -0.02 & 0.99 \\
\hline Sex (female) & -16.7 & 0.001 & -0.01 & 0.99 \\
\hline Number of beehives (10-25) & -0.52 & 0.59 & -0.78 & 0.43 \\
\hline Number of beehives (>25) & 0.01 & 1.01 & 0.02 & 0.99 \\
\hline Education (higher) & 1.46 & 4.29 & 3.03 & $<0.001^{* *}$ \\
\hline Family (bigger) & -1.01 & 0.36 & -2.46 & $0.01^{*}$ \\
\hline Age (41-55) & -1.96 & 0.14 & -3.07 & $<0.001^{* *}$ \\
\hline Age (>55) & -0.55 & 0.57 & -1.08 & 0.28 \\
\hline Professional (Yes) & 0.08 & 1.05 & 0.01 & 0.99 \\
\hline
\end{tabular}

Significant at ${ }^{*} p<0.05,{ }^{* *} p<0.01$.

\section{Discussion}

The findings of this research show that socio-demographic factors influence the adoption of new technologies and investments in R\&D in the Serbian beekeepers association. Our findings point out that the higher the level of education and professional beekeeping influenced the willingness to invest in research and development. A higher level of education has predicts the willingness to hire professional consultants or bodies for the research and development of beekeeping practices, therefore our first hypothesis has been confirmed. Female Serbian beekeepers, beekeepers aged over 41 and professionally engaged beekeepers are more likely to admit that they need the support of scientific and research institutions in the further development of beekeeping practices. Thus, the second hypothesis has also been confirmed. The respondents with larger families and those who have between 10 and 25 beehives were more likely to agree that significant funds and further research in the development of beekeeping practices is needed. It is interesting to note that beekeepers that have more than 25 beehives and those with a higher education were less likely to agree that significant investments and further research in the development of beekeeping are needed. The beekeeping association members' age 
and professional engagement in beekeeping did not prove to be significant predictors, so the third hypothesis has been partially confirmed. The following findings point out that the Serbian beekeepers who are more educated and who have more than 25 beehives are possibly well aware of current research, and already use the incentives available to the beekeepers by the state or province and thus consider that may consider that no additional significant investments and further research are needed. A higher number of beehives, level of education and family members (more than four members) predicted the easier adoption of new technologies in large families, as they may consider that their productivity as well as income can be increased which is significant, especially for the household income of large families, therefore these findings confirm our forth hypothesis. The findings are in line with the study findings [45] that show that the improved technology adoption was higher in households involving both genders in beekeeping activities, while the findings have shown the relationship between the number of honeybee colonies, extent of improved technology adoption, honey yield and farm income from beekeeping. The finding of a study [46] on the economic performance of the new beekeeping technology, in comparison with the traditional one, has shown that the modern technology assures a $48 \%$ higher profit than in case of classic technology. A higher education has been shown to be the strongest significant predictor of a new technology increase of value added hive products (such as royal jelly, propolis, bee pollen and beeswax). The higher education exerted the highest positive influence on new technology adoption therefore the fifth hypothesis has been confirmed. The findings are in line with a study on the use of modern beehive technology, which revealed that the education was an important factor [47]. The findings are in line with Keiyoro et al. [44], who concluded that in female beekeeping groups, the education levels (among several other factors) can positively influence the adoption of new technologies. The findings are also confirmed by the authors of a study on the innovative potential of beekeeping production in AP Vojvodina [3], which has concluded that "the basic recommendations for encouraging the introduction of innovations in beekeeping are providing adequate and relevant agricultural advisory services, provision of credit services to beekeepers for the purchase of modern equipment; incentives for the introduction of innovations" (p. 276).

\section{Conclusions}

This research paper focuses on how members of the society of beekeepers, that have developed a product that is traditionally manufactured in the specific region of Fruška Gora, perceive the investment in the R\&D and the adoption of new technologies in beekeeping. The socio-demographic characteristics of beekeepers (sex, number of hives, education, family size, age and engagement in beekeeping) have been analyzed to see whether they influence the adoption of new technologies and the investment in $R \& D$. The findings show that the majority of Serbian beekeepers have a very high level of awareness of the level of education positively influencing the adoption of new technologies. A positive influence of the education level on new technology adoption has also been proven. Serbian beekeepers are well aware that further research in the field of beekeeping is needed and would be willing to hire experts in the research and development of beekeeping practices. Higher education has had an influence on the adoption of new technology with the aim of increasing the production towards the value added hive products (such as royal jelly, propolis, bee pollen and beeswax). Therefore, several conclusions could be drawn. Firstly, the authors can conclude that the education on sustainable beekeeping practices and new technology adoption should be supported by national beekeeping education programs, in accordance with the best practices of EU beekeeping programs. Secondly, the further promotion of beekeeping as a potentially profitable and environmentally-friendly business, of honey with the protected geographical indication, is an important marketing tool and the consumers, on the other hand, should recognize the product as having a higher quality than other similar products. Because of the low consumer purchasing power in the Serbian market, the cheaper substitutes for honey, which are largely present on the market, may appeal more to consumers. This constitutes a major threat. The findings on the Polish food-processing industry after their EU accession has shown the higher importance of quality guarantees and successful branding in international activities, whereas the importance of taste and 
price is higher in domestic market [55]. In this regard the quality of the honey represents a chance to contribute to a greater visibility of the "Fruška Gora linden honey" in the market. Thirdly, the initiatives aimed at encouraging cooperation and R\&D with different faculties and research institutes should nurture further apiculture research [56]. This implies that the potential for R\&D in the apiculture sector, and the adoption of new technologies in the apiculture communities, is still not fully exploited with a need to be further investigated.

The issue of raising the efficiency in honey production and enhancing the export potential of the apiculture sector was traditionally based on increasing the number of hives. However, the authors point out that the modernization of production, the education of beekeepers and the organizational improvements are essential parts of an increased competitiveness of the sector. The authors stress the necessity of improving all the factors of competitiveness in the apiculture sector, in relation to their economic strength and the level of the entrepreneurial approach. Beekeepers do need increased institutional support, but the expansion of the beekeeper network and the efficient use of production resources represent a significant factor. By defining targeted measures to encourage beekeeping production, the state has an important role in ensuring the simulative conditions for the apiculture sector in the country. This would be a step forward in the development of beekeeping, which is in line with the beekeepers stated willingness to invest in R\&D activities and to cooperate with professional consultants. By adopting new technologies and directing activities and investments in $R \& D$, the potential of the apiculture can be further exploited, thus ensuring the positive impact of beekeeping on the overall development of agriculture.

On the basis of the study findings, the following practical recommendations can be outlined. Awareness creation can be raised through intensive training and workshops for the beekeepers. Experts of different faculties and research institutes, willing to work with the society of beekeepers, need to assure service provisions to beekeepers with the aim of assuring help and support in the introduction of the new technologies and promotion of investment in the R\&D. The management staff of the society of beekeepers can be trained to improve their management skills in terms of offering members a better placement of honey on the local market, as it can have a significant effect on promoting honey production and honey quality. In view of the foregoing, all the stakeholders should work towards creating an enabling environment in which beekeeping entrepreneurs can exploit opportunities to provide economic security to local communities as a basic or additional income generating activity. A measure on cooperation with the specialized bodies for the implementation of applied research programs in the field of beekeeping and apiculture products, is already included in the national programs developed by member states, provides co-financing of $50 \%$ by the European Union. For example, in the Croatian National Beekeeping Program, for the period from 2020 to 2022, the same measure (financing mutual cooperation in applied research programs) that is relevant for improving beekeeping conditions through supplementation and building new knowledge was introduced in the following thematic areas: bee diseases and pests and their interactions, the conservation of bee biodiversity and the impact of the environment on bee communities, the confirmation of the authenticity of the species, geographical origin and the manner of production of bee products (honey, royal jelly, pollen, propolis, wax) [57]. The National Rural Development Program of the Republic of Serbia from 2018 to 2020 offers financial support to beekeepers, only in terms of subsidies per hive and the procurement of beekeeping equipment [58]. In the future, also prior to EU accession, the Serbian National Association of Beekeepers should initiate the adoption of the national program for the development of beekeeping that also includes a measure on increasing the mutual cooperation in applied research programs. By harmonizing domestic legislation with European legislation in the field of honey production, the domestic producers should have more support (that in the future could be equivalent to the support provided by European honey producers), which would in turn contribute to improving the competitiveness of Serbian honey producers and a better recognition of honey from the Republic of Serbia on the European market. 
Since this survey targeted its resources exclusively among the members of the society of beekeepers in the specific region of "Fruška Gora", it is questionable if the conclusions could be generalized to be taken as representative. The researchers suggest that similar research be carried out in different locations of the country and in different beekeeping societies/associations, to establish other possible influences. Then the findings of the following study could be compared to the sociocultural factors in different regions and the beekeepers' willingness to adopt new beekeeping technologies or professional advice from specialized bodies. The originality of this paper stems from the need to investigate further sources of uniting traditional beekeeping with the perceived investment in R\&D and the adoption of new technologies in order to investigate their future performance. The perceived willingness of beekeepers to invest in the R\&D and the adoption of new technologies, especially for the honey products of protected geographical indications, has not been exploited enough and deserves further attention.

Author Contributions: Conceptualization, J.V.-T.; methodology, J.V.-T.; software, V.M.-J.; validation, S.S., G.R. and J.V.-T.; formal analysis, D.J.; investigation, S.S.; resources, G.R.; data curation, V.M.-J.; writing-original draft preparation, J.V.-T.; writing-review and editing, V.M.-J.; visualization, S.S.; supervision, G.R.; project administration, S.S.; funding acquisition, D.J. All authors have read and agreed to the published version of the manuscript.

Funding: This research received no external funding.

Conflicts of Interest: The authors declare no conflict of interest.

\section{References}

1. Vapa-Tankosić, J.; Mirković, Z.; Ignjatijević, S. Economic incentive measures and legal framework in the field of beekeeping in the European Union. Ecologica 2018, 25, 29-35.

2. Vapa-Tankosić, J.; Ignjatijević, S.; Kiurski, J.; Milenković, J.; Milojević, I. Analysis of Consumers' Willingness to Pay for Organic and Local Honey in Serbia. Sustainability 2020, 12, 4686. [CrossRef]

3. Prodanović, R.; Ignjatijević, S.; Bošković, J. Innovative potential of beekeeping production in AP Vojvodina. J. Agron. Technol. Eng. Manag. 2019, 2, 268-277.

4. Chauzat, M.-P.; Cauquil, L.; Roy, L.; Franco, S.; Hendrikx, P.; Ribière-Chabert, M. Demographics of the European Apicultural Industry. PLoS ONE 2013, 8, e79018. [CrossRef] [PubMed]

5. EU. Agricultural Product Quality Policy. Available online: https://ec.europa.eu/info/food-farming-fisheries/ food-safety-and-quality/certification/quality-labels/quality-schemes-explained_en (accessed on 21 June 2020).

6. Jovanović, D.; Milenković, N.; Damjanović, R. Ocenjivanje i predviđanje potreba potrošača. Oditor 2017, 3, 71-79.

7. Milosavljević, S.; Pantelejić, Đ.; Međedović, D. Primena i mogućnost unapređenja ekonomskih činilaca u realizaciji održivog razvoja. Održiv. Razvoj 2019, 1,7-16. [CrossRef]

8. Ignjatijevic, S.; Cvijanović, D. Exploring the Global Competitiveness of Agri-Food Sectors and Serbia's Dominant Presence: Emerging Research and Opportunities. In Advances in Business Strategy and Competitive Advantage; IGI Global: Hershey, PA, USA, 2017.

9. Ignjatijević, S.; Milojević, I.; Andžić, R. Economic analysis of exporting Serbian honey. Int. Food Agribus. Manag. Rev. 2018, 21, 929-944. [CrossRef]

10. Vapa-Tankosić, J.; Redžepagić, S.; Stojsavljević, M. Trade, Regional Integration and Economic Growth: MEDA Region and the Western Balkan Countries. In Financial Integration; Springer: Berlin/Heidelberg, Germany, 2013; Volume 36, pp. 215-229. ISBN 978-3-642-35696-4.

11. Ignjatijević, S.; Matijašević, J.; Milojević, I. Revealed comparative advantages and competitiveness of the processed food sector for the Danube countries. Custos E Agronegocio Line 2014, 10, 256-281.

12. Raičević, V.; Ignjatijević, S.; Matijašević, J. Economic and legal determinants of export competitiveness of the food industry of Serbia. Industrija 2012, 40, 201-226.

13. Ignjatijević, S.; Čavlin, M.; Djordjevic, D. Measurement of comparative advantages of processed food sector of Serbia in the increasing the export. Econ. Agric. 2014, 61, 677-693. [CrossRef] 
14. Ignjatijević, S.; Prodanović, R.; Bošković, J.; Puvača, N.; Tomaš-Simin, M.; Peulić, T.; Đuragić, O. Comparative analysis of honey consumption in Romania, Italy and Serbia. Food Feed Res. 2019, 46, 125-136. [CrossRef]

15. Ignjatijević, S.; Milojević, I.; Cvijanović, G.; Jandrić, M. Balance of Comparative Advantages in the Processed Food Sector of the Danube Countries. Sustainability 2015, 7, 6976-6993. [CrossRef]

16. Bertozzi, L. Designation of origin: Quality and specification. Food Qual. Prefer. 1995, 6, 143-147. [CrossRef]

17. Pocol, C.B.; Ignjatijević, S.; Cavicchioli, D. Production and Trade of Honey in Selected European Countries: Serbia, Romania and Italy. In Honey Analysis; InTech: Rijeka, Croatia, 2017; pp. 1-20.

18. Commission Regulation (EC) No 1845/2004 of 22 October 2004 Supplementing the Annex to Regulation (EC) No 2400/96 on the Entry of Certain Names in the Register of Protected Designations of Origin and

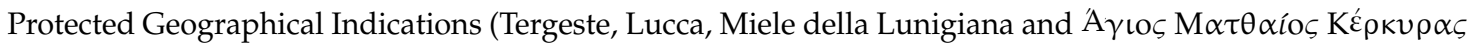
(Agios Mathaios Kerkyras)). Available online: http://www.legislation.gov.uk/eur/2004/1845/annex/division/1 (accessed on 21 June 2020).

19. Union, P.O. of the E. Commission Implementing Regulation (EU) No 243/2011 of 11 March 2011 Entering a Name in the Register of Protected Designations of Origin and Protected Geographical Indications (Oravský korbáčik (PGI). CELEX1. Available online: http://op.europa.eu/en/publication-detail/-/publication/4c0e50383947-4c84-98be-f8158a6c4e2e/language-en (accessed on 21 June 2020).

20. Commission Implementing Regulation (EU) No 328/2014 of 26 March 2014 Entering a Name in the Register of Protected Designations of Origin and Protected Geographical Indications (Miele Varesino (PDO)) EUR-Lex-32014R0328-EN-EUR-Lex. Available online: https://eur-lex.europa.eu/legal-content/EN/ALL/?uri= CELEX\%3A32014R0328 (accessed on 21 June 2020).

21. Ministry of Agriculture and Rural Development and Romanian Beekeepers Association. Romanian Presidency of the Council of the European Union: Romania's Environmental Mission and Priorities. EIRP Proc. 2019, 14. Available online: https://ec.europa.eu/environment/eir/pdf/report_ro_en.pdf (accessed on 20 July 2020).

22. Ćirić, M.; Ignjatijević, S.; Cvijanović, D. Research of honey consumers' behavior in province of Vojvodina. Ekon. Poljoprivred. 2015, 62, 627-644. [CrossRef]

23. Ferreira, M.L.B.; Arnaud, E.D.R.; Leite, D.T.; Sousa, L.C.F.S.; Schmidt, F.R. Social environmental and economic study of family production of the beekeepers cooperative of Catole do Rocha. Rev. Verde De Agroecol. E Desenvolv. Sustent. 2012, 7, 34-44.

24. Ramadani, V.; Hisrich, R.D.; Dana, L.-P.; Palalic, R.; Panthi, L. Beekeeping as a family artisan entrepreneurship business. Int. J. Entrep. Behav. Res. 2019, 25, 717-730. [CrossRef]

25. Androulidakis, S.; Harizanis, P. Identification of Greek beekeepers' educational needs, a case study. Eur. J. Agric. Educ. Ext. 1996, 3, 47-53. [CrossRef]

26. Semkiw, P.; Skubida, P. Evaluation of the economical aspects of Polish Beekeeping. J. Apic. Sci. 2010, 54, 10-12.

27. Pocol, C.B. Sustainable policies for the development of beekeeping in Romania. Probl. Rol. Świat. 2011, 11, 3.

28. Popa, A.A.; Mărghitaş, L.A.; Pocol, C.B. Economic and socio-demographic factors that influence beekeepers' entrepreneurial behavior. Agron. Ser. Sci. Res. 2011, 54, 450-455.

29. Gomes, M.; Casaca, J.; Cabo, P.; Dias, L.G.; Vilas Boas, M. Trade barriers and economic impact of organic beekeeping in Portugal. In Book of Abstracts of the Ind International Symposium on Bee Products, Annual Meeting of the International Honey Commission; School of Agriculture, Polytechnic Institute of Bragança: Braganca, Portugal, 2012; pp. 38-39.

30. Lengler, L.; Lago, A.; Coronel, D.A. A organização associativa no setor apícola: Contribuições e potencialidades. Org. Rurais Agroind. 2011, 9, 152-163.

31. Pocol, C.; Moldovan-Teselios, C.; Arion, F.H. Beekeepersâ Association: Motivations and Expectations. Bull. Univ. Agric. Sci. Vet. Med. Cluj Napoca Hortic. 2014, 71, 141-147.

32. Mushonga, B.; Hategekimana, L.; Habarugira, G.; Kandiwa, E.; Samkange, A.; Ernest Segwagwe, B.V. Characterization of the Beekeeping Value Chain: Challenges, Perceptions, Limitations, and Opportunities for Beekeepers in Kayonza District, Rwanda. Adv. Agric. 2019, 2019, 1-9. [CrossRef]

33. Ismail, M.M.; Ismail, W.I.W. Development of stingless beekeeping projects in Malaysia. E3S Web. Conf. 2018, 52, 00028. [CrossRef] 
34. Grgić, Z.; Filipi, J.; Bićanić, D.; Bobić, B.Š. Opportunities for developing a business model of Mediterranean beekeeping. J. Cent. Eur. Agric. 2017, 19, 206-216. Available online: https://hrcak.srce.hr/507719 (accessed on 10 May 2020).

35. Grgić, Z.; Filipi, J.; Bićanić, D.; Šakić Bobić, B. Opportunities for developing a business model of Mediterranean beekeeping. J. Cent. Eur. Agric. 2018, 19, 287-296. [CrossRef]

36. Tesser, F.; Cavicchioli, D. Economic Aspects of Beekeeping and Honey Production in Italy and in Lombardy Region; Museo Lombardo di Storia dell'Agricoltura, Sant'Angelo Lodigiano: Lodi, Italy, 2014; Volume 1, pp. 41-52.

37. Pocol, C.B.; Marghitas, L.A.; Popa, A.A. Evaluation of sustainability of the beekeeping sector in the North West Region of Romania. J. Food Agric. Environ. 2012, 10, 132-138.

38. Praća, N.; Paspalj, M.; Paspalj, D. Ekonomska analiza uticaja savremene poljoprivrede na održivi ravoj. Oditor 2017, 3, 37-51. [CrossRef]

39. Plavša, N.; Stojanović, D.; Stojanov, I.; Puvača, N.; Stanaćev, V.; Đuričić, B. Evaluation of oxytetracycline in the prevention of American foulbrood in bee colonies. AJAR 2011, 6, 1621-1626. [CrossRef]

40. Puvača, N.; Lika, E.; Cocoli, S.; Shtylla Kika, T.; Bursić, V.; Vuković, G.; Tomaš Simin, M.; Petrović, A.; Cara, M. Use of Tea Tree Essential Oil (Melaleuca alternifolia) in Laying Hen's Nutrition on Performance and Egg Fatty Acid Profile as a Promising Sustainable Organic Agricultural Tool. Sustainability 2020, 12, 3420. [CrossRef]

41. Pocol, C.B.; Bârsan, A.; Popa, A.A. A model of social entrepreneurship developed in Barču Valley, Slaj County. Analele Univ. Din Oradea Fasc. Ecotoxicol. Zooteh. Si Tehnol. De Ind. Aliment. 2012, 11, 183-190.

42. Cvijanović, D.; Ignjatijević, S.; Vapa Tankosić, J.; Cvijanović, V. Do Local Food Products Contribute to Sustainable Economic Development? Sustainability 2020, 12, 2847. [CrossRef]

43. Schot, J.; Steinmueller, W.E. Three frames for innovation policy: R\&D, systems of innovation and transformative change. Res. Policy 2018, 47, 1554-1567. [CrossRef]

44. Keiyoro, P.N.; Muya, B.I.; Gakuo, C.M.; Mugo, K. Impact of Sociocultural factors on adoption of modern technologies in beekeeping projects among women groups in Kajiado County- Kenya. IJIER 2016, 4, 55-64. [CrossRef]

45. Bhusal, S.; Thapa, R. Comparative Study on the Adoption of Improved Beekeeping Technology for Poverty Alleviation. J. Inst. Agric. Anim. Sci. 2005, 26, 117-125. [CrossRef]

46. Popescu, A.; Siceanu, A. Economic efficiency of various queen bees maintenance systems. J. Cent. Eur. Agric. 2003, 4, 153-160.

47. Yehuala, S.; Birhan, M.; Melak, D. Perception of Farmers towards the Use of Modern Beehives Technology in Amhara Region, Ethiopia. Engineering 2013, 5, 1-8.

48. Eforuoky, F.; Thomas, K.A.; Eforuoky, F.; Thomas, K.A. Effect of training on the use of modern beekeeping technologies in Oyo State, Nigeria. Niger. J. Rural Sociol. 2015, 15, 61-66. [CrossRef]

49. Gürer, B.; Akyol, E. The determinants of technical efficiency in beekeeping farms and the role of agricultural subsidies: The case of Nigde, Turkey. J. Agric. Environ. Int. Dev. 2018, 112, 343-360. [CrossRef]

50. Suraj, S.; Das, D. Factors affecting adoption of beekeeping and associated technologies in Kamrup (rural) district, Assam state, India. BIJ 2018, 2, 253-258. [CrossRef]

51. Muya, B.I.; Gakuu, C.M.; Keiyoro, P.N. Economic factors influencing adoption of modern beekeeping technologies among women beekeeping projects in Kajiado county- Kenya. Int. J. Curr. Res. 2018, 10, 72779-72782.

52. Walford, G.; Tucker, E.; Viswanathan, M. The SAGE Handbook of Measurement; SAGE: London, UK, 2010; ISBN 978-1-4462-0688-1.

53. Hayes, B.E. Measuring Customer Satisfaction: Development and Use of Questionnaires; Irwin Professional Pub: Milwaukee, WI, USA, 1992; ISBN 978-0-87389-131-8.

54. Harrell, F.E. Regression Modeling Strategies: With Applications to Linear Models, Logistic and Ordinal Regression, and Survival Analysis; Springer International Publishing: Cham, Switzerland, 2015; ISBN 978-3-319-19424-0.

55. Bryla, P. The impact of EU accession on the marketing strategies of Polish food companies. Br. Food J. 2012, 114, 1196-1209. [CrossRef]

56. Cristina, R.; Kovačević, Z.; Cincović, M.; Dumitrescu, E.; Muselin, F.; Imre, K.; Militaru, D.; Mederle, N.; Radulov, I.; Hădărugă, N.; et al. Composition of a Natural Phytotherapeutic Association Beneficially Used to Combat Nosemosis in Honey Bees. Sustainability 2020, in press. 
57. Ministry of Agriculture, National Beekeeping Program for the Period from 2020 to 2022. Available online: https://poljoprivreda.gov.hr/UserDocsImages/dokumenti/poljoprivreda/pcelarstvo/ Nacionalni\%20p\%C4\%8Derlarski\%20program\%202020.-2022.pdf (accessed on 12 July 2020).

58. Nacionalni Program Ruralnog Razvoja od 2018. do 2020. godine. Available online: /subvencije_regulative_u_poljoprivredi_detalji/ministarstvo_poljoprivrede_donelo_je_nacionalni_ programruralnog_razvoja_od_2018_do_2020_godine-1533643094 (accessed on 13 July 2020). 